\title{
ZATRUDNIENIE BIAŁORUSINÓW W POLSCE W LATACH 2010-2017
}

\section{Streszczenie}

Cel - W artykule skupiono się na poznaniu przyczyn wzmożonego napływu imigrantów zarobkowych z Białorusi do Polski, a za czas analizy przyjęto lata 2010-2017.

Metodyka badania - W celu pogłębienia analizy, wykorzystano dane Ministerstwa Rodziny, Pracy i Polityki Społecznej.

Wynik - Migracje zarobkowe, których celem jest poprawa sytuacji życiowej własnej i członków rodziny, są nieodłącznym elementem rynku pracy. Kluczowym problemem stało sie zróżnicowanie zatrudnienia Białorusinów w Polsce z podziałem na branże i płeć oraz w układzie wojewódzkim.

Oryginalność/Wartość - Zbadanie poziomu zatrudnienia Białorusinów na polskim rynku pracy, które jest zjawiskiem coraz bardziej powszechnym, jednak wciąż stosunkowo nieznanym.

Słowa kluczowe: rynek pracy, zatrudnienie, zezwolenie na pracę, Białorusini

\section{EMPLOYMENT OF BELARUSIANS ON POLISH LABOUR MARKET IN 2010-2017}

\section{Summary}

Goal - The article focuses on recognizing the causes of increased inflow of labor immigrants from Belarus in Poland, for the analysis time, adopting the years 2010-2017.

Research methodology - In order to deepen the analysis, the author used data from the Ministry of Family, Labor and Social Policy.

Score - Economic migrations for purposes of improving life situation are an inseparable element of the labor market. The key problem addressed in the article is the diversification of employment of Belarusians in Poland presented by industry, gender and voivodships.

Originality /value - Prospecting the employment rate of Belarusians on the Polish labor market, which is an increasingly common phenomenon, but still unknown.

Key words: labor market, employment, work permit, Belarussians

DOI: $10.15290 /$ wpewbmn3.2019.03 


\section{Wprowadzenie}

Obecnie Polacy należą do najszybciej starzejących się społeczeństw na świecie. W 2016 roku osoby w wieku produkcyjnym stanowiły $61,8 \%$ ogółu ludności ${ }^{1}$. Z prognozy ludności, opracowanej przez GUS na lata 2014-2050, wynika, że w 2030 roku wartość ta spadnie do $61,5 \%$, a w roku 2050 wyniesie jedynie 56,1\% ${ }^{2}$. Już teraz agencje pośrednictwa odnotowują zapotrzebowanie na pracowników tymczasowych, przewyższające liczbę osób chętnych do podjęcia pracy opartej na tej formie zatrudnienia. Napływ imigrantów jest jedną z najlepszych metod rozwiązania problemu niedoboru siły roboczej w Polsce ${ }^{3}$. Biorąc pod uwagę fakt, że napływowi pracowników cudzoziemskich nieodłącznie towarzyszy odpływ pracowników polskich poza granice państwa, bardzo ważne jest prowadzenie przez Polskę przemyślanej polityki imigracyjnej, mającej na celu zachowanie równowagi na rynku pracy. Transformacja ustrojowa Polski oraz liberalizacja przepisów wizowych po 1989 roku przyczyniły się do większego napływu imigrantów. W poszukiwaniu lepszych warunków do życia, do Polski zaczęło przybywać coraz więcej obywateli byłego Związku Radzieckiego.

\section{Udział Białorusinów w stosunku do ogółu obcokrajowców zatrudnionych w Polsce}

Według Narodowego Spisu Powszechnego przeprowadzonego w 2011 roku, wśród cudzoziemców zamieszkujących na stałe w Polsce, najwięcej było: Ukraińców, Niemców, Rosjan, Białorusinów i Wietnamczyków ${ }^{4}$.

Polskie prawo stanowi, że cudzoziemiec pochodzący z państw spoza Unii Europejskiej oraz państw Europejskiego Obszaru Gospodarczego, chcący pracować legalnie w Polsce, jest zobowiązany do uzyskania zezwolenia na pracę ${ }^{5}$. Pracodawca, który zamierza zatrudnić obywatela Białorusi na terenie Polski, musi uzyskać dla niego zezwolenie na pracę, składając wniosek we właściwym urzędzie wojewódzkim. Białorusini, posiadający Kartę Polaka, są zwolnieni z obowiązku uzyskania zezwolenia na pracę. Ponadto, bez zezwolenia mogą pracować w Polsce obywatele Białorusi, którzy posiadają status studenta bądź pracownika

\footnotetext{
${ }^{1}$ Rocznik demograficzny 2017, GUS, Warszawa 2017, s. 162.

${ }^{2}$ Prognoza ludności na lata 2014-2050, GUS, https://stat.gov.pl/obszarytematyczne/ludnosc/ prognozaludnosci/prognoza-ludnosci-na-lata-2014-2050-opracowana-2014-r-,1,5.html [data dostępu: 10.05.2017].

${ }^{3}$ T. Kupczyk, Ocena imigrantów z Ukrainy przez polskich pracodawców na przykładzie opinii klientów Otto Work Force Polska, [w:] Imigranci wsparciem dla rynku pracy i rozwoju przedsiębiorstw, T. Kupczyk (red.), Wydawnictwo „Gazety Wyborczej”, Wrocław 2017, s. 18-19. ${ }^{4}$ A. Organiściak-Krzykowska, Popyt na pracę cudzoziemców w Polsce, [w:] Popyt na pracę cudzoziemców, A. Organiściak-Krzykowska, M. Piotrowski, K. Nyklewicz, A. Skórska, L. Kucharski (red.), Wydawnictwo Uniwersytetu Warmińsko-Mazurskiego, Olsztyn 2013, s. 16.

${ }^{5}$ Ustawa $z$ dnia 20 kwietnia 2004 r. o promocji zatrudnienia i instytucjach rynku pracy, Dz. U. 2013,1650, art. 87.
} 
naukowego i mają zezwolenie na zamieszkanie na okres studiów lub prowadzenia badań naukowych ${ }^{6}$.

Z obowiązku posiadania zezwolenia są także zwolnieni Białorusini, którzy wykonują określone prace na terenie Polski, np. pomoc domowa czy praca na stanowisku opiekunki, jak również osoby, które wykonują zawody deficytowe albo takie, na które jest niewielka podaż na polskim rynku pracy. Niestety, nadal wielu obcokrajowców pracuje w Polsce bez zezwoleń, tzw. na czarno ${ }^{7}$. Niniejsza analiza obejmuje Białorusinów legalnie zatrudnionych w Polsce na podstawie posiadanego zezwolenia na pracę.

Wykres 1.

Liczba zezwoleń na pracę wydanych cudzoziemcom w Polsce w 2017 roku, ze względu na kraj pochodzenia

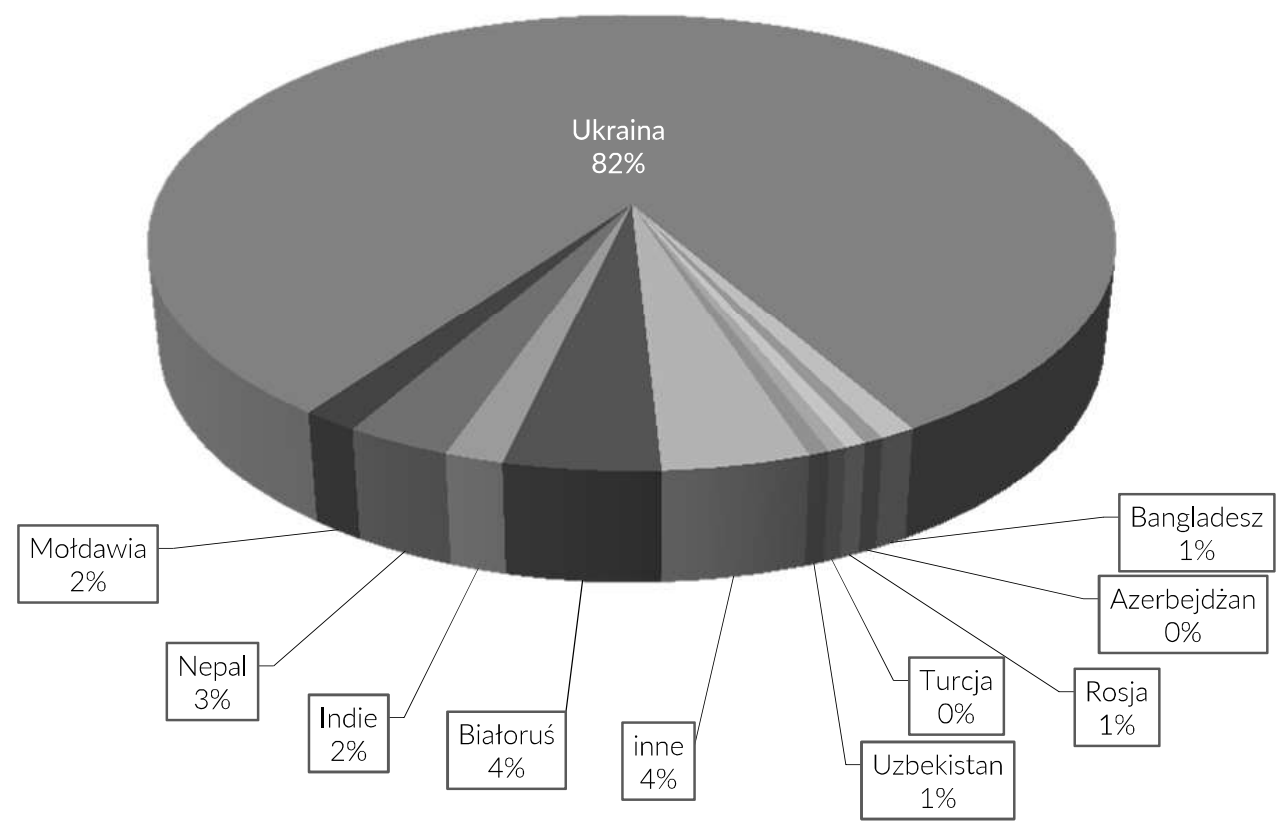

Źródło: opracowanie własne na podstawie: Zezwolenia na pracę cudzoziemców, https://www.mpips.gov.pl/analizy-i-raporty/cudzoziemcy-pracujacy-w-polsce-statystyki [data dostępu: 10.05.2018].

Najliczniejszymi grupami cudzoziemców, pracujących w Polsce w latach 2010-2017, byli: Ukraińcy, Białorusini, Nepalczycy, Hindusi i Mołdawianie (wy-

${ }^{6}$ Z. Wafflard, Zatrudnianie cudzoziemców niebędacych obywatelami UE, [w:] Praktyka zatrudniania cudzoziemców w Polsce, M. Ciara, K. Klimek, A. Korkus, M. Kozłowska, B. Lenart, Z. Wafflard (red.), Wydawnictwo C.H. Beck, Warszawa 2013, s. 30-31.

${ }^{7}$ J.M. Szaban, Rynek pracy $w$ Polsce i w Unii Europejskiej, Wydawnictwo Difin, Warszawa 2013, s. 164-165. 
kres 1.). Obywatele Białorusi zajęli drugie miejsce pod względem liczby cudzoziemców, którzy otrzymali zezwolenie na pracę w Polsce w badanych latach, w 2017 roku (4,5\% ogółu zezwoleń). W tym zakresie najliczniejszą grupę stanowili obywatele Ukrainy. Liczba wydanych zezwoleń dla Ukraińców w 2017 roku stanowiła $82 \%$ ogółu zezwoleń na pracę wydanych cudzoziemcom.

Na podstawie danych zawartych w tabeli 1. można zauważyć, że 2017 rok był rekordowy zarówno pod względem liczby wydanych zezwoleń na pracę cudzoziemców, jak i pod względem zezwoleń wydanych dla Białorusinów zgłaszających chęć podjęcia pracy w Polsce. W 2017 roku liczba wydanych pozwoleń na pracę dla obywateli Białorusi wzrosła ponad pięciokrotnie w stosunku do 2010 roku.

Tabela 1.

Liczba zezwoleń na pracę wydanych cudzoziemcom w Polsce w latach 2010-2017, z uwzględnieniem obywateli Białorusi

\begin{tabular}{l|c|c|c|c|c|c|c|c}
\hline $\begin{array}{l}\text { Zezwolenie według } \\
\text { kraju pochodzenia }\end{array}$ & 2010 & 2011 & 2012 & 2013 & 2014 & 2015 & 2016 & 2017 \\
\hline $\begin{array}{l}\text { Cudzoziemcy } \\
\text { ogółem }\end{array}$ & 36622 & 40808 & 39144 & 39078 & 43663 & 65786 & 127394 & 235626 \\
\hline Białorusini & 1937 & 1725 & 1949 & 2004 & 1834 & 2037 & 4870 & 10518 \\
\hline
\end{tabular}

Źródło: opracowanie własne na podstawie: Zezwolenia na pracę cudzoziemców, op. cit.

Wśród Białorusinów przyjeżdżających do Polski w celach zarobkowych, największą grupę stanowi młode pokolenie ${ }^{8}$. Przeciętny, młody obywatel, nieposiadający własnego domu, zagrożony trudnymi warunkami życia, wizją bezrobocia bądź niemający gwarancji znalezienia pracy w wyuczonym zawodzie, chętnie wyjeżdża za granicę, w tym także do Polski, z nadzieją na poprawę jakości swojego życia. Młode pokolenie Białorusinów nie ma problemu $\mathrm{z}$ emigracją w poszukiwaniu pracy, ponieważ jest dobrze wykształcone, dysponuje szerokim zakresem wiedzy o świecie i dosyć często jest sceptycznie nastawione do panującej władzy. Inaczej jest w przypadku „starszego” społeczeństwa Białorusi o silnym poczuciu tożsamości narodowej. Są to osoby bardzo związane z tradycją i kulturą białoruską, niechętnie opuszczające granice państwa ${ }^{9}$.

Analizując wzrost zatrudnienia tak Białorusinów, jak i ogółu cudzoziemców w Polsce po 2014 roku, należy zwrócić uwagę na wzrost płac minimalnych w badanym okresie. Jeszcze w 2014 roku najniższa krajowa pensja brutto wynosiła 1680 zł, a w roku 2016 już 1850 zł brutto ${ }^{10}$. W 2017 roku wzrosła o $12 \%$ w stosunku do 2016 roku i wynosiła 2000 zł brutto. Dla porównania, minimalna

\footnotetext{
${ }^{8}$ J. Tymanowski, Rola i znaczenie Republiki Białoruś we wspótczesnej Europie, Wydawnictwo Adam Marszałek, Toruń 2017, s. 184-187.

${ }^{9}$ Ibidem.

${ }^{10}$ Sytuacja makroekonomiczna $w$ Polsce na tle procesów $w$ gospodarce światowej $w 2016$ roku, GUS, Warszawa 2017, s. 118.
} 
płaca krajowa na Białorusi w 2017 roku wynosiła 265 rubli białoruskich ${ }^{11}$, co w przeliczeniu na złotówki, zgodnie z kursem walut z dnia 26 maja 2018 roku, wynosi około $485 \mathrm{zf}^{12}$. Napływowi zagranicznej siły roboczej w 2016 roku sprzyjała również fala odejść polskich pracowników z prac o niskim wynagrodzeniu wraz z wprowadzeniem programu 500+ w kwietniu 2016 roku. Z pracy przede wszystkim zwalniali się budowlańcy, sprzątaczki, pracownicy firm ochroniarskich czy sprzedawcy, czyli pracownicy zawodów o niskim prestiżu i minimalnych płacach ${ }^{13}$. Skutkiem tego było poszerzenie rynku pracy o oferty pracy, z których zrezygnowali Polscy pracownicy. Zaistniała sytuacja jest intratna dla imigrantów z Białorusi, przyjeżdżających do Polski w celu podjęcia pracy, a nie $\mathrm{w}$ celach pobierania zasiłków lub korzystania $\mathrm{z}$ innych form pomocy społecznej ${ }^{14}$. Kolejnym czynnikiem, zachęcającym obcokrajowców do podjęcia pracy na terenie Polski, może być pewnego rodzaju sukces polskiego rynku pracy, którym jest wyraźna poprawa sytuacji na tle krajów Unii Europejskiej, przejawiająca się zmniejszeniem dystansu oddzielającego Polskę od średniej Unii Europejskiej w zakresie głównych wskaźników opisujących sytuację na rynku pracy. Chociaż wskaźnik zatrudnienia w Polsce pozostaje na zdecydowanie niższym poziomie niż wynosi średnia w Unii Europejskiej, to jego wartość od 2010 roku wzrasta, a to oznacza, że coraz więcej ludzi znajduje prace w swoim zawodzie. W Polsce jeszcze w 2010 roku wskaźnik zatrudnienia wynosił 58,9\% i był o 5,2\% niższy, niż w Unii Europejskiej. W 2017 roku wyniósł $66,5 \%$ i był jedynie o1,7\% niższy od średniej unijnej ${ }^{15}$.

\section{Struktura branżowa zatrudniania Białorusinów w Polsce}

Białorusini na polskim rynku pracy są zatrudniani zazwyczaj poniżej poziomu swojego wykształcenia, w zawodach o niskich płacach oraz niższym prestiżu, które są niechętnie wykonywane przez Polaków. Można zatem stwierdzić, że w zatrudnianiu Białorusinów w Polsce jest zauważalny dualizm rynku pracy i tym samym rynek pracy został podzielony na dwa segmenty. Występują tzw. dobre i złe miejsca pracy, a obywatele Białorusi mają bardzo ograniczone szanse dostępu do lepszych miejsc pracy, które są obłożone dużą podażą pracy ze strony polskich obywateli ${ }^{16}$.

\footnotetext{
${ }^{11}$ Trading Economics, https://pl.tradingeconomics.com/belarus/minimum-wages [data dostępu: 10.05.2018].

${ }^{12}$ Wykres średnich kursów kantorowych, Rubel białoruski(BYN), http://kantory.pl/wykresy/byn [data dostępu: 26.05.2018].

${ }^{13}$ K. Potapenko, Wptyw imigrantów z Ukrainy na stan rynku pracy $w$ Polsce, [w:] Rynek pracy $w$ Polsce-szanse i zagrożenia, K. Pujer (red.), Exante, Wrocław 2016, s. 93.

${ }^{14}$ Ibidem.

${ }^{15}$ Rynek Pracy $w$ Polsce $w 2017$ roku, MRPiPS, Departament Rynku Pracy, Warszawa 06.03. 2018 r., https://www.mpips.gov.pl/analizy-i-raporty/raporty-sprawozdania/rynek-pracy/sytuacja-na-rynku-pracy/rynek-pracy-w-polsce-w-2017-roku [data dostępu: 10.05.2018].

${ }^{16}$ A. Organiściak-Krzykowska, Popyt na pracę cudzoziemców w Polsce ..., op. cit., s. 21-22.
} 
Analiza zezwoleń na pracę wydanych Białorusinom z podziałem na sekcje PKD, zawarta w tabeli 2., pokazuje, że najwięcej zezwoleń na pracę dla Białorusinów zostało wydanych w transporcie i gospodarce magazynowej (około 54\% w 2017 roku) oraz w budownictwie (20,4\% w 2017 roku). W latach 2010-2017 nastąpił spadek zainteresowania pracą w sekcji handlu hurtowego i detalicznego. W 2010 roku liczba wydanych zezwoleń na pracę w tej sekcji wyniosła prawie $11 \%$, a już w 2017 roku jedynie $3,1 \%$. Z danych w tabeli 2 . także wynika, iż zawody z: sekcji edukacji, opieki zdrowotnej i pomocy społecznej, działalności finansowej i ubezpieczeniowej oraz rolnictwa, leśnictwa, łowiectwa i rybactwa w badanych latach cieszyły się najmniejszym zainteresowaniem wśród obywateli Białorusi. Zauważalny był również spadek zezwoleń na pracę w gospodarstwach domowych wydanych po 2014 roku, gdzie w latach 2010-2014 ponad 3\% Białorusinów otrzymywało zezwolenia na pracę $\mathrm{w}$ tej kategorii.

Tabela 2 .

Udział wybranych sekcji PKD w ogólnej liczbie zezwoleń wydanych Białorusinom w latach 2010-2017 (w \%)

\begin{tabular}{|c|c|c|c|c|c|c|c|c|}
\hline sekcja PKD & 2010 & 2011 & 2012 & 2013 & 2014 & 2015 & 2016 & 2017 \\
\hline $\begin{array}{l}\text { rolnictwo, leśnictwo, łowiectwo } \\
\text { i rybactwo }\end{array}$ & 0,6 & 0,5 & 0,8 & 0,7 & 0,9 & 0,5 & 0,3 & 0,5 \\
\hline przetwórstwo przemysłowe & 4,6 & 3,2 & 2,4 & 1,4 & 0,9 & 0,5 & 1,0 & 6,2 \\
\hline budownictwo & 17,0 & 14,7 & 14,7 & 16,5 & 14,4 & 9,5 & 10,9 & 20,4 \\
\hline handel hurtowy i detaliczny & 10,6 & 9,3 & 9,2 & 9,6 & 8,3 & 6,3 & 4,4 & 3,1 \\
\hline transport i gospodarka magazynowa & 32,2 & 41,0 & 50,8 & 49,8 & 57,4 & 70,8 & 70,4 & 54,0 \\
\hline $\begin{array}{l}\text { działalność związana } \\
\text { z zakwaterowaniem i usługami } \\
\text { gastronomicznymi }\end{array}$ & 1,2 & 1,0 & 1,2 & 1,3 & 1,8 & 0,3 & 0,3 & 0,7 \\
\hline informacja i komunikacja & 0,2 & 2,5 & 3,9 & 2,6 & 2,0 & 1,8 & 1,9 & 1,3 \\
\hline $\begin{array}{l}\text { działalność finansowa } \\
\text { i ubezpieczeniowa }\end{array}$ & 0,3 & 0,2 & 0,2 & 0,2 & 0,3 & 0,3 & 0,1 & 0,1 \\
\hline $\begin{array}{l}\text { działalność profesjonalna, } \\
\text { naukowa i techniczna }\end{array}$ & 3,6 & 2,4 & 2,4 & 2,1 & 1,9 & 1,4 & 2,1 & 1,9 \\
\hline edukacja & 0,4 & 1,0 & 1,0 & 0,8 & 0,3 & 0,2 & 0,1 & 0,1 \\
\hline $\begin{array}{l}\text { opieka zdrowotna i pomoc } \\
\text { społeczna }\end{array}$ & 0,2 & 0,4 & 0,4 & 0,3 & 0,2 & 0,1 & 0,1 & 0,02 \\
\hline $\begin{array}{l}\text { gospodarstwa domowe } \\
\text { zatrudniające pracowników }\end{array}$ & 3,2 & 3,5 & 3,5 & 3,7 & 3,9 & 2,8 & 1,1 & 0,6 \\
\hline
\end{tabular}

Źródło: opracowanie własne na podstawie: Zezwolenia na pracę cudzoziemców, op. cit.

W Polsce praca w sekcji gospodarstw domowych jest zajęciem najchętniej podejmowanym przez Białorusinki. Imigrantki najczęściej znajdują zatrudnienie w pracach opiekuńczych, pełniąc opiekę nad dziećmi, osobami starszymi i chorymi lub jako opiekunki domu, gdzie ich praca polega na sprzątaniu i gotowa- 
niu ${ }^{17}$. Większość z zezwoleń na pracę w Polsce wydanych Białorusinom dotyczyła mężczyzn (wykres 2.). Białorusinki, które otrzymały zezwolenie na pracę w Polsce w latach 2010-2014, stanowiły średnio 17\% ogółu Białorusinów, którym wydano zezwolenie. Od 2015 roku zauważa się spadek procentowego udziału kobiet w kształtowaniu tej wartości i choć wzrosła liczba zezwoleń wydanych również kobietom, to jest to niewielki odsetek w porównaniu z zezwoleniami wydanymi mężczyznom. W 2017 roku pozwolenia wydane kobietom wynosiły jedynie niecałe $8 \%$, pozostałe $92 \%$ to zezwolenia na pracę wydane mężczyznom. Zazwyczaj kobiety rzadziej emigrują zarobkowo, niż mężczyźni. Taka tendencja jest także zachowana w przypadku emigracji zarobkowej Białorusinek. Imigrantki obejmują problemową grupę na rynku pracy i napotykają wiele barier, uniemożliwiających podjęcie pracy za granicą. Do głównych zalicza się niewyrozumiałość pracodawców dla kobiet w ciąży i pracownic-matek oraz dylemat opuszczania swoich dzieci w kraju pochodzenia ${ }^{18}$.

Wykres 2.

Liczba zezwoleń na pracę wydanych obywatelom Białorusi w latach 2011-2017, z podziałem na płeć

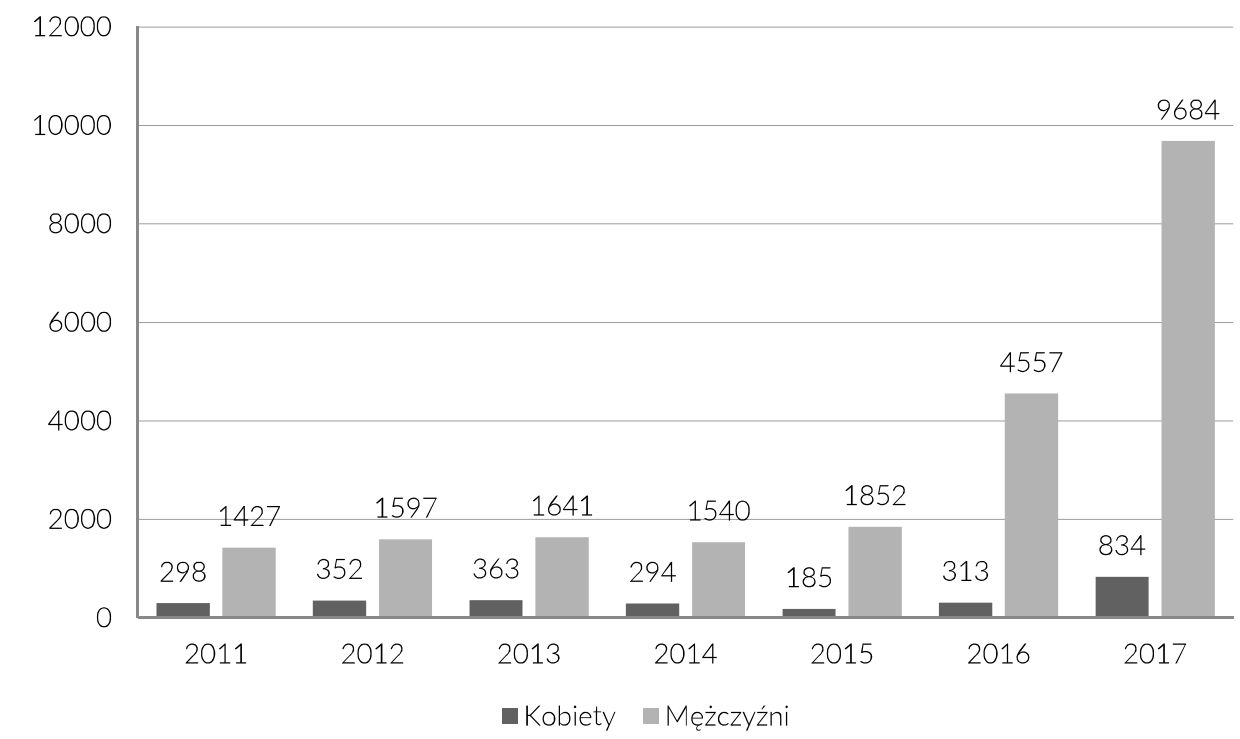

Źródło: opracowanie własne na podstawie: Zezwolenia na pracę cudzoziemców, op. cit.

\footnotetext{
${ }^{17}$ J. Mazur, Imigracyjny kontekst polskiej polityki społecznej: dylematy $i$ wyzwania, [w:] Prawne i ekonomiczne aspekty imigracji do Polski, M. Butrymowicz, P. Kroczek (red.), Wydawnictwo Naukowe Uniwersytetu Papieskiego Jana Pawła II w Krakowie, Kraków 2017, s. 61.

${ }^{18}$ A. Balicka, Grupy problemowe na polskim rynku pracy, [w:] Rynek pracy w Polsce - szanse i zagrożenia, K. Pujer (red.), Exante, Wrocław 2016, s. 82-83.
} 


\section{Struktura przestrzenna zatrudniania Białorusinów w Polsce}

Za główny czynnik, warunkujący koncentrację Białorusinów w konkretnym regionie Polski, uznaje się występowanie dużego podmiotu gospodarczego na danym obszarze, jak również sytuację na rynku pracy w poszczególnych regionach. Miejscem najchętniej wybieranym do pracy przez wszystkich cudzoziemców, a także przez Białorusinów, jest województwo mazowieckie. Dzięki swojemu nieustannemu i dynamicznemu rozwojowi, Warszawa przyciąga inwestycje krajowe i zagraniczne, generujące nowe miejsca pracy, a dobra sytuacja na warszawskim rynku pracy spowodowała, że miasto stało się atrakcyjne dla cudzoziemców ${ }^{19}$.

Dane zawarte w tabeli 3., dotyczące struktury przestrzennej wydanych zezwoleń na pracę, wskazują, że w 2017 roku najwięcej zezwoleń na pracę dla Białorusinów wydano w województwie mazowieckim (aż 44,5\% ogółu zezwoleń).

Tabela 3.

Zezwolenia na pracę wydane obywatelom Białorusi w 2017 roku, według województw

\begin{tabular}{l|c|c}
\hline \multicolumn{1}{c|}{ Województwo } & Liczba zezwoleń & Odsetek zezwoleń \\
\hline mazowieckie & 4683 & $44,52 \%$ \\
\hline lubelskie & 1809 & $17,20 \%$ \\
\hline podlaskie & 914 & $8,69 \%$ \\
\hline tódzkie & 547 & $5,20 \%$ \\
\hline pomorskie & 445 & $4,23 \%$ \\
\hline warmińsko-mazurskie & 407 & $3,87 \%$ \\
\hline śląskie & 404 & $3,84 \%$ \\
\hline wielkopolskie & 293 & $2,79 \%$ \\
\hline zachodniopomorskie & 241 & $2,29 \%$ \\
\hline małopolskie & 228 & $2,17 \%$ \\
\hline dolnośląskie & 140 & $1,33 \%$ \\
\hline lubuskie & 138 & $1,31 \%$ \\
\hline kujawsko-pomorskie & 79 & $0,75 \%$ \\
\hline świętokrzyskie & 71 & $0,68 \%$ \\
\hline podkarpackie & 60 & $0,57 \%$ \\
\hline opolskie & 59 & $0,56 \%$ \\
\hline Ogółem & 10518 & $100 \%$ \\
\hline
\end{tabular}

Źródło: opracowanie własne na podstawie: Zezwolenia na pracę cudzoziemców, op. cit.

Jednocześnie Białorusini jako miejsce do pracy chętnie wybierali województwa położone w północno-wschodniej Polsce, takie jak: lubelskie, podlaskie czy

\footnotetext{
${ }^{19}$ A. Organiściak-Krzykowska, Popyt na pracę cudzoziemców w Polsce, op. cit., s. 26-29.
} 
warmińsko-mazurskie. Szukając przyczyn wysokiego zatrudnienia Białorusinów w północno-wschodniej Polsce, należy przede wszystkim wskazać położenie geograficzne tych województw.

Czynnikiem, który determinuje wyższe zatrudnienie w tych regionach, jest zarazem zbliżona kultura, mentalność oraz brak bariery językowej. Polacy, zamieszkujący wschodnie granice państwa, są bardziej obyci z językiem rosyjskim, niż ci zamieszkujący środkowe czy zachodnie części kraju. Ponadto, przedsiębiorstwa ze wschodniej części Polski deklarują większy niedobór odpowiednio wykwalifikowanych pracowników. Otwarcie zagranicznych rynków pracy zdecydowanie przyczyniło się do migracji rodzimych pracowników za granicę, a co za tym idzie, wystąpienia deficytu zasobów pracy pozostających w dyspozycji przedsiębiorstw ${ }^{20}$.

Polskie przedsiębiorstwa coraz chętniej zatrudniają Białorusinów, ze względu na: wspomniane wcześniej niedobory kadrowe wśród pracowników, niższe żądania płacowe oraz dobrą znajomość języków obcych. Poza tym, dużym atutem zatrudniania Białorusinów w Polsce są ich zagraniczne kontakty, często umożliwiające rozwój przedsiębiorstwa i ekspansję na inne kraje. Największą barierę w zatrudnianiu cudzoziemców spoza Unii Europejskiej w Polsce, w tym także z Białorusi, stanowi czasochłonność procedur administracyjnych, które należałoby uprościć. W tym przypadku skutecznym rozwiązaniem byłoby zmniejszenie liczby niezbędnych załączników dołączanych przy składaniu wniosku o wydanie zezwolenia na pracę ${ }^{21}$.

\section{Podsumowanie}

Bliskość językowa, kulturowa, poprawa sytuacji polskiego rynku pracy oraz wzrost płacy minimalnej w badanych latach to tylko kilka z czynników sprzyjających migracji zarobkowej Białorusinów do Polski.

Chociaż udział migrantów z Białorusi na Polskim rynku pracy nie odgrywa kluczowej roli w polskiej strukturze zatrudnienia, to w badanych latach widocznie wzrosło ich znaczenie. Biorąc pod uwagę zmiany struktury demograficznej Polski i prognozę na kolejne lata, należy spodziewać się, że tendencja zatrudniania obcokrajowców, w tym także Białorusinów, w Polsce będzie utrwalać się w przyszłości. Co więcej, Białorusini obejmują duży odsetek wszystkich cudzoziemców pracujących w Polsce. Tworzą drugą, najliczniejszą grupę, zaraz po obywatelach Ukrainy.

Najczęściej Białorusini na polskim rynku pracy są zatrudniani na budowach, w branżach transportowych, w handlu, przetwórstwie, czyli tam, gdzie występuje deficyt rodzimych pracowników. Imigrantki z Białorusi wpisują się we wzorce

\footnotetext{
${ }^{20}$ A. Organiściak Krzykowska, M. Piotrowski, Badanie popytu na pracę cudzoziemców w Polsce Wschodniej, op. cit., s. 80-82.

${ }^{21}$ Ibidem, s. 96-98.
} 
„ekonomii opieki”, najczęściej podejmując pracę jako pomoc domowa, sprzątaczka lub opiekunka, a więc w tych sektorach, w których Polki nie chcą pracować. Jednak należy z dużą ostrożnością podchodzić do traktowania pracowników z Białorusi jako rezerwuaru siły roboczej, który ma uzupełniać niedobory na polskim rynku pracy.

\section{Literatura}

Balicka A., Grupy problemowe na polskim rynku pracy, [w:] Rynek pracy $w$ Polsce - szanse i zagrożenia, K. Pujer (red.), Exante, Wrocław 2016.

Kupczyk T., Ocena imigrantów z Ukrainy przez polskich pracodawców na przykładzie opinii klientów Otto Work Force Polska, [w:] Imigranci wsparciem dla rynku pracy i rozwoju przedsiębiorstw, T. Kupczyk (red.), Wydawnictwo Gazety Wyborczej, Wrocław 2017.

Mazur J., Imigracyjny kontekst polskiej polityki społecznej: dylematy i wyzwania, [w:] Prawne i ekonomiczne aspekty imigracji do Polski, M. Butrymowicz, P. Kroczek (red.), Wydawnictwo Naukowe Uniwersytetu Papieskiego Jana Pawła II w Krakowie, Kraków 2017.

Organiściak-Krzykowska A., Piotrowski M., Badanie popytu na pracę cudzoziemców w Polsce Wschodniej, [w:] Popyt na pracę cudzoziemców, A. Organiściak-Krzykowska, M. Piotrowski, K. Nyklewicz, A. Skórska, L. Kucharski (red.), Wydawnictwo Uniwersytetu Warmińsko-Mazurskiego, Olsztyn 2013.

Organiściak-Krzykowska A., Popyt na pracę cudzoziemców w Polsce, [w:] Popyt na pracę cudzoziemców, A. Organiściak-Krzykowska, M. Piotrowski, K. Nyklewicz, A. Skórska, L. Kucharski, (red.) Wydawnictwo Uniwersytetu Warmińsko-Mazurskiego, Olsztyn 2013.

Potapenko K., Wpływ imigrantów z Ukrainy na stan rynku pracy w Polsce, [w:] Rynek pracy w Polsce-szanse i zagrożenia, K. Pujer (red.), Exante, Wrocław 2016.

Rocznik demograficzny 2017, GUS, Warszawa 2017.

Sytuacja makroekonomiczna $w$ Polsce na tle procesów w gospodarce światowej $w 2016$ roku, GUS, Warszawa 2017.

Szaban J.M., Rynek pracy w Polsce i w Unii Europejskiej, Wydawnictwo Difin, Warszawa 2013.

Tymanowski J., Rola i znaczenie Republiki Białoruś we współczesnej Europie, Wydawnictwo Adam Marszałek, Toruń 2017.

Ustawa z dnia 20 kwietnia 2004 r. o promocji zatrudnienia i instytucjach rynku pracy, Dz. U. 2013,1650.

Wafflard Z., Zatrudnianie cudzoziemców niebędacych obywatelami UE, [w:] Praktyka zatrudniania cudzoziemców w Polsce, M. Ciara, K. Klimek, A. Korkus, M. Kozłowska, B. Lenart, Z. Wafflard (red.), Wydawnictwo C.H. Beck, Warszawa 2013. 


\section{Materiały elektroniczne}

Cudzoziemcy pracujący w Polsce, Analizy i Raporty, MRPiPS, https://www.mpips.gov.pl/ analizy-i-raporty/cudzoziemcy-pracujacy-w-polsce-statystyki [data dostępu: 10.05. 2018].

Prognoza ludności na lata 2014-2050, GUS, https://stat.gov.pl/obszary-tematyczne/ ludnosc/prognoza-ludnosci/prognoza-ludnosci-na-lata-2014-2050-opracowana2014-r-,1,5.html [data dostępu: 10.05.2017].

Rynek Pracy $w$ Polsce w 2017 roku, MRPiPS, Departament Rynku Pracy, Warszawa 06.03.2018, https://www.mpips.gov.pl/analizy-i-raporty/raporty-sprawozdania/rynek-pracy/sytuacja-na-rynku-pracy/rynek-pracy-w-polsce-w-2017-roku [data dostępu: 10.05 .2018$]$.

Trading Economics, https://pl.tradingeconomics.com/belarus/minimum-wages [data dostępu: 10.05.2018].

Wykres średnich kursów kantorowych, Rubel białoruski (BYN), http://kantory.pl/wykresy/ byn [data dostępu: 26.05.2018].

Zezwolenia na pracę cudzoziemców, MRPiPS, https://www.mpips.gov.pl/analizy-i-raporty/ cudzoziemcy-pracujacy-w-polsce-statystyki [data dostępu: 10.05.2018]. 